\title{
VASODILATATION IN THE LOWER EXTREMITIES IN RESPONSE TO IMMERSING THE FOREARMS IN WARM WATER
}

\author{
By JOHN H. GIBBON, JR., AND EUGENE M. LANDIS \\ (From the Robinette Foundation of the Hospital of the University of Pennsylvania, \\ Philadelphia)
}

(Received for publication May 26, 1932)

Several tests have been proposed, and are now in general use, for estimating the grade of organic occlusion existing in the blood vessels of an extremity. The principle underlying these various methods is similar. The surface temperature of the distal portion of the cool, exposed extremity is measured thermo-electrically. Dilatation of the peripheral vessels is then produced and the coincident rise in surface temperature is recorded. The level to which the temperature rises with complete vasodilatation has been determined in individuals with normal peripheral circulation. If the surface temperature fails to rise to this normal level, the arteries supplying the part are regarded as being unable to dilate due to organic changes in their walls.

One of the earliest methods of producing vasodilatation in the extremities in man was suggested by Brown (1) and consists in producing fever by the intravenous injection of typhoid vaccine. Morton and Scott (2) induced vasodilatation in the lower limbs by means of spinal anesthesia, and later proposed the use of general anesthesia, ether, nitrous oxide or ethylene (3), for the same purpose. Injection of peripheral nerves with novocaine has also been used to produce local vasodilatation by White (4), Lewis (5), and Scott and Morton (6). Still more recently Lewis and Pickering (7) studied the vasodilatation in the hands produced by warming the body. The subject was seated in a small hot air chamber with the head and hands projecting into a cool room. Heating the air in the chamber to a temperature of $46^{\circ} \mathrm{C}$. or more was followed by a rise in the skin temperature of the hands. They suggest that the method may also be used to produce vasodilatation in the feet.

The following report describes the effects which warming one or two extremities exerts on the skin temperature of the other extremities, with special emphasis on the vasodilatation in the feet produced by immersing the forearms in warm water. The mechanism by which this vasodilatation is induced has been studied in normal subjects. The simplicity of the method and apparatus, as well as the constancy of the reaction in normal subjects, suggests that the procedure may have a certain value in the 
diagnosis of peripheral vascular diseases. Only three illustrative cases are described; a more comprehensive clinical study will appear later.

\section{METHOD}

The observations on normal subjects have been carried out at room temperatures varying from 11.4 to $21.5^{\circ} \mathrm{C}$. The subjects were seated in a chair with the feet resting on a stool about a foot from the floor. Room temperature was read from a mercury thermometer suspended in the air near the exposed extremities. The surface temperatures of the toes were determined thermo-electrically in the usual manner. The thermal junctions were placed in contact with the skin on the dorsal surface of the distal phalanx just proximal to the base of the nail. In some instances the junctions were bare and in others a single layer of surgeon's plaster covered the junction without modifying the results significantly. Skin temperatures were measured at 2 minute intervals while the exposed extremities cooled, and when the skin temperature was sufficiently low (usually $25^{\circ} \mathrm{C}$. or less) the forearms were immersed in warm water (43 to $45^{\circ} \mathrm{C}$.) to a point just above the elbows. For this purpose ordinary white enamel arm baths, $52 \mathrm{~cm}$. long, $20 \mathrm{~cm}$. wide and $15 \mathrm{~cm}$. deep, were entirely satisfactory. The temperature of the water was kept between 43 and $45^{\circ} \mathrm{C}$. by means of a small electrical heating coil placed beneath each bath. While the forearms were immersed in warm water skin temperature and room temperature were read every minute.

While the primary object of these experiments was to study vasodilatation in the lower extremities, a certain number of observations were made upon the vasodilatation in the hands produced by immersing the legs in warm water. In these experiments the method was essentially the same. The hands were exposed until cool, then the legs were immersed in warm water to a level midway between the ankle and knee. The two receptacles used as foot baths were metal cans, open at the top, $24 \mathrm{~cm}$. square and $35 \mathrm{~cm}$. deep. At the bottom of each can a small wooden frame weighted with lead prevented the sole of the foot from coming into contact with the metal. The bath was maintained at a temperature of 43 to $45^{\circ} \mathrm{C}$. by means of a small heating coil beneath each can.

\section{OBSERVATIONS}

\section{General vasodilator effects of immersing one or two extremities in warm water}

The typical rise in the skin temperature of the feet observed when the hands and forearms are immersed in warm water is shown in Figure 1. The subject (G.) had been in a cool room (16 to $17^{\circ}$ C.) for two hours. The coat was removed and the shirt sleeves were rolled up above the elbows. The subject was seated; his feet were supported about 15 inches from the floor and exposed to the room air. Thermal junctions 
were placed on the right first and second and the left first toes. During the first 20 minutes of exposure the temperatures of the toes fell from between 19 and $20^{\circ} \mathrm{C}$. to between 17 and $18^{\circ} \mathrm{C}$. Both arms were then immersed in warm water $\left(44\right.$ to $45.5^{\circ} \mathrm{C}$.). Four minutes later the subject felt warm; one minute after that the face was flushed and the forehead slightly moist with perspiration. Ten minutes after the forearms had been immersed the subject was perspiring profusely. The left first toe started to become warm ten minutes after the forearms had been immersed and was followed three minutes later by the right first and second toes.

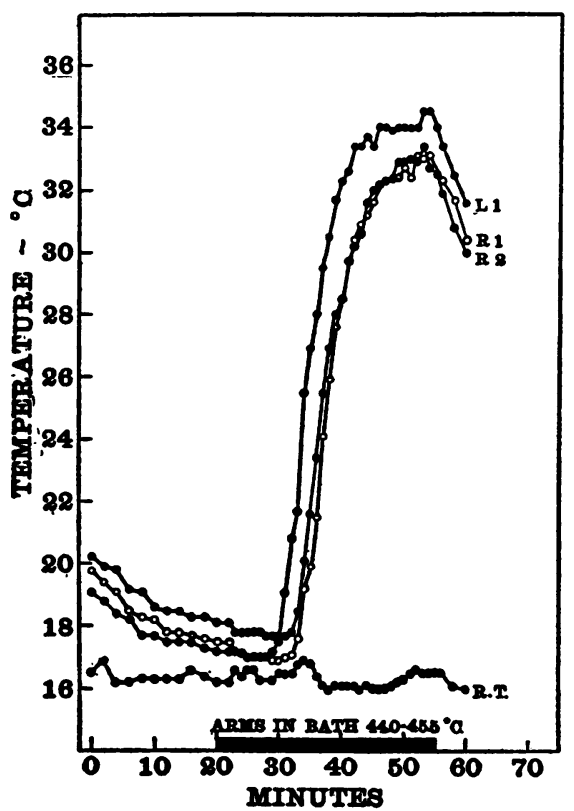

Fig. 1. Showing Vasodilatation in the Toes Produced by Immersing Both Forearms in Warm Water

$L 1$, left first toe; $R 1, R 2$, right first and second toes; $R$. $T$., room temperature.

Thereafter the skin temperature of all the toes rose rapidly, reaching in a few minutes maximum levels of 33 to $34^{\circ} \mathrm{C}$. The forearms were removed from the warm water 35 minutes after being immersed. This was followed by a rapid fall in the surface temperature of the toes.

The normal vasodilator response in the hands following immersion of the legs in warm water is shown in Figure 2. The subject, La., entered the cool room $\left(14^{\circ} \mathrm{C}\right.$.) after having been in a warm environment for several hours. Coat, shoes and socks were removed, and the shirt sleeves were rolled above the elbows. The subject was seated in a chair with his hands resting palm downward on a table. Thermal junctions were placed over the dorsum of the middle phalanx of the left third and right 
fourth fingers and on the dorsum of the right hand. In this observation the rectal temperature was also recorded by means of a fourth thermal junction placed opposite the opening of a small catheter introduced into the rectum for a distance of $10 \mathrm{~cm}$. Surface temperatures were then recorded for a preliminary period of 73 minutes. During the first 30 minutes the surface temperatures of the hand and fingers fell slowly. By the 30th minute the subject felt definitely chilly, and from then on the

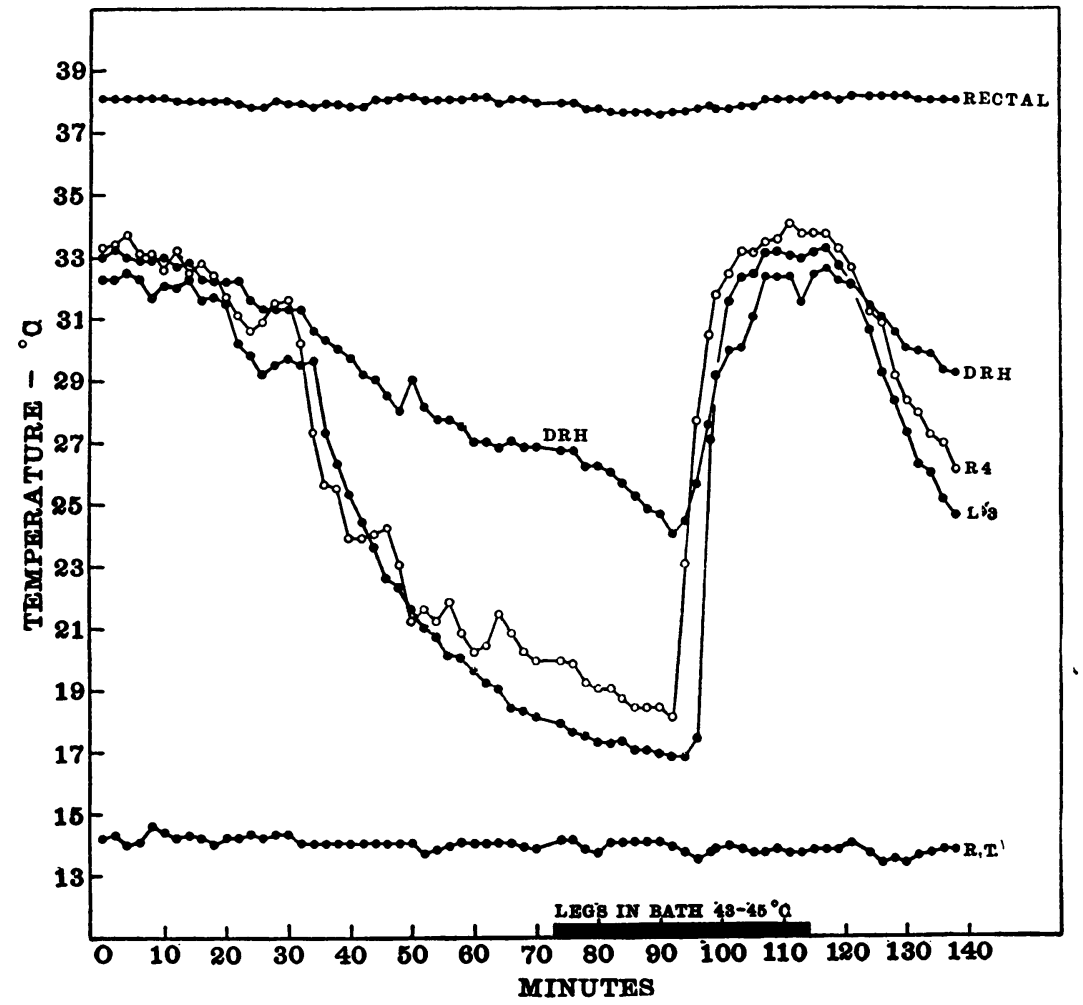

Fig. 2. Showing Vasodilatation in the Fingers Produced by Immersing Both Lower Legs in Warm Water. Rectal Temperature is SHOWN AT TOP OF Chart.

$D R H$, dorsum right hand; $R 4$, right fourth finger; $L 3$, left third finger; $R . T$., room temperature.

surface temperatures fell more rapidly. At the $73 \mathrm{~d}$ minute both lower legs were immersed in water at a temperature of 43 to $45^{\circ} \mathrm{C}$. Ten minutes after immersion of the legs the subject still felt definitely chilly and gooseflesh was present over both the forearms. Six minutes later the subject was comfortably warm and the forehead was moist to the touch. After the legs had been immersed 19 minutes the temperatures of the fingers and hand began to rise and in a few minutes had exceeded $32^{\circ} \mathrm{C}$. 
After the legs had been removed from the baths and dried, the temperatures of the hand and fingers began to fall and the subject again felt chilly.

It can be seen in Figure 2 that the temperature of the dorsum of the hand, although initially higher than that of the fingers, did not rise as rapidly nor to as high a level as did the digital temperature. Lewis and Pickering (7) have demonstrated that the tips of the fingers show the earliest and greatest rise in surface temperature when vasodilatation is induced by warming the body. These authors have suggested that the difference in temperature response is due to the presence in the distal phalanges of arteriovenous anastomoses, the importance of which Grant and Bland (8) have demonstrated.

Warming a sufficient area of one limb also produces vasodilatation in the other limbs. Figure 3 shows the effect of warming the lower half of

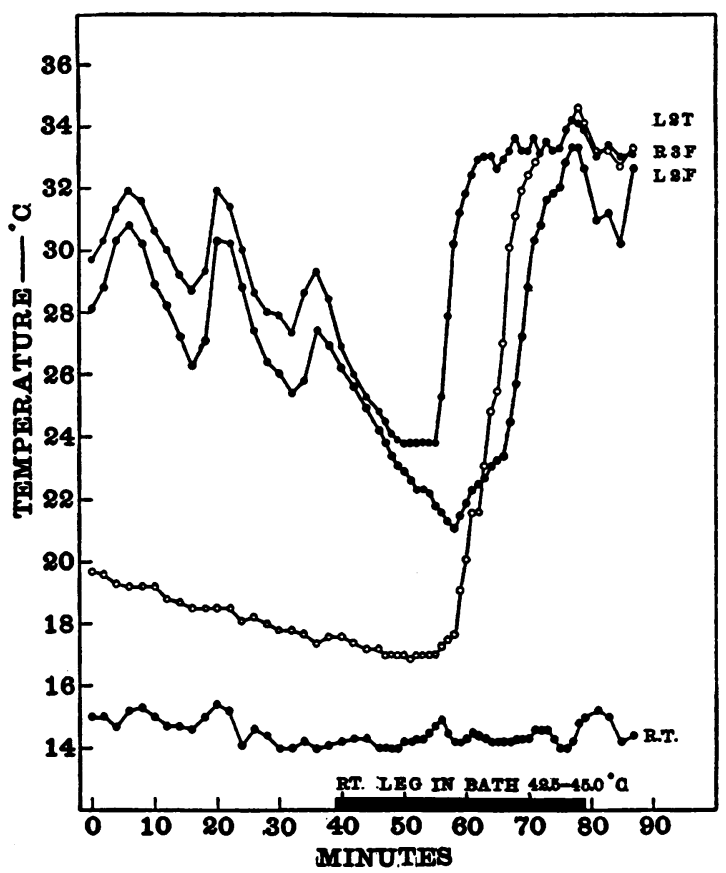

Fig. 3. Showing Vasodilator Effect of Immersing the Right Lower LEG IN WARM WATER

$L 2 T$, left second toe; $R 3 F$, right third finger; $L 2 F$, left second finger; $R . T$., room temperature.

the right leg upon the surface temperatures of the other three extremities. During the control period of 39 minutes the temperature of the left second toe, which was already at a low level $\left(19.7^{\circ} \mathrm{C}\right.$.), fell steadily. The 
temperatures of the fingers fluctuated about a high level at the start of the observation but finally began to fall as the subject became definitely chilly. At the 39th minute the right lower leg was immersed in a bath at a temperature of 42.5 to $45^{\circ} \mathrm{C}$. Sixteen minutes after the leg was immersed the subject still felt definitely chilly. Three minutes later the face was flushed and by the 60th minute, 21 minutes after immersion of the leg, the subject felt comfortably warm. Shortly afterward the temperatures of all three extremities had risen well above $32^{\circ} \mathrm{C}$. Immersion of one forearm in hot water produces a similar rise of skin temperature in the opposite fingers and in the toes (Figure 4).

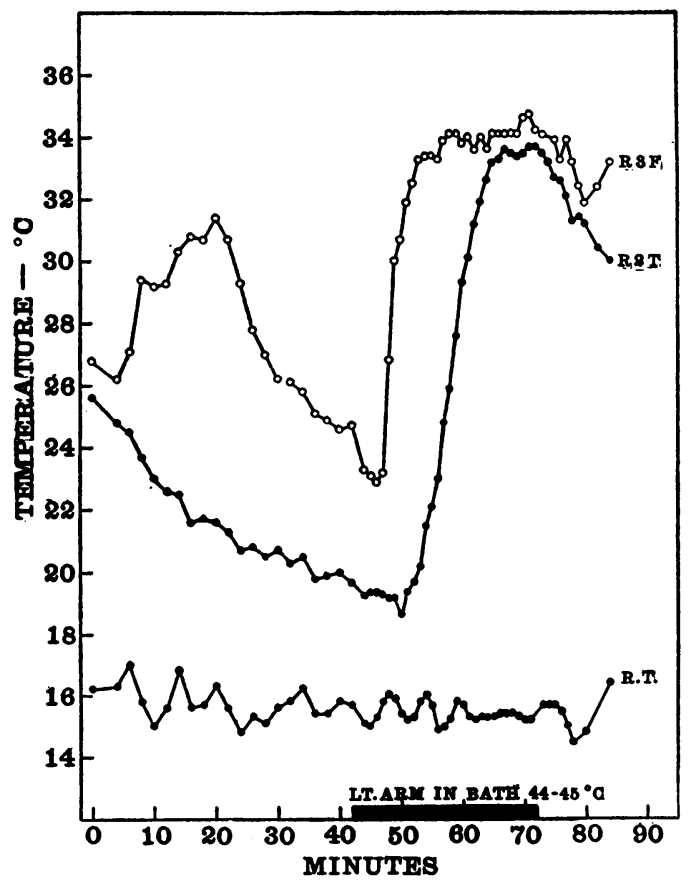

Fig. 4. Showing Vasodilator Effect of Immersing the Left Forearm IN WARM WATER

$R 3 F$, right third finger; $R 2 T$, right second toe; $R . T$., room temperature.

In normal subjects warming two extremities in the manner described has always produced complete vasodilatation in the digits of the other two extremities. Warming one extremity, however, does not always produce complete vasodilatation in the other three extremities. Such partial or incomplete responses have been observed when one upper extremity has been warmed only as far as the wrist, or when one lower extremity has been warmed only as far as the ankle. 


\section{The time relations of the vasodilator response in the lower extremities of normal subjects}

Table I summarizes the results of immersing the hands and forearms of six normal subjects in warm water. The room temperatures varied between 11.4 and $21.5^{\circ} \mathrm{C}$. The temperatures of the toes before the rise ranged from 16.9 to $28.5^{\circ} \mathrm{C}$. In all but the last observation the feet were cooled by exposing them to room air. After such spontaneous cooling the skin temperature began to rise within 3 to 15 minutes after the forearms were immersed, reaching $32^{\circ} \mathrm{C}$. within 7 to 29 minutes after the beginning of the immersion. Usually 3 or 4 toes were observed in each subject and in every instance but one the temperature finally rose to values exceeding $32^{\circ} \mathrm{C}$. In this one exception after the forearms had been immersed for 35 minutes the temperature of one toe was 31.6 while the others had reached $32.1,33.1$ and $33.6^{\circ} \mathrm{C}$. The thermocouple later proved to be defective so that this exception may not be a real one. The skin temperature of the digits always rose above that level which Morton and Scott (3) regard as the minimum normal response to spinal anesthesia (i.e. $31.5^{\circ}$ C.).

TABLE I

The vasodilatation produced in the feet by warming the arms

\begin{tabular}{|c|c|c|c|c|c|c|}
\hline Subject & $\begin{array}{c}\text { Room } \\
\text { temperature }\end{array}$ & Toe & $\begin{array}{c}\text { Temperature } \\
\text { of toe } \\
\text { before rise }\end{array}$ & $\begin{array}{c}\text { Time from } \\
\text { immersion } \\
\text { to start of rise }\end{array}$ & $\begin{array}{l}\text { Time to } \\
\text { reach } \\
32^{\circ} \mathrm{C} .\end{array}$ & $\begin{array}{c}\text { Maximum } \\
\text { temperature }\end{array}$ \\
\hline G. & $\begin{array}{l}\bullet C . \\
16.5\end{array}$ & $\begin{array}{l}\text { R1 } \\
\text { R2 } \\
\text { L1 }\end{array}$ & $\begin{array}{l}\circ C . \\
16.9 \\
17.7 \\
17.0\end{array}$ & $\begin{array}{c}\text { minutes } \\
12 \\
13 \\
10\end{array}$ & $\begin{array}{c}\text { minutes } \\
25 \\
26 \\
20\end{array}$ & $\begin{array}{l}{ }^{\circ} C . \\
33.2 \\
33.4 \\
34.5\end{array}$ \\
\hline G. & 20.0 & $\begin{array}{l}\text { R1 } \\
\text { L1 } \\
\text { L3 }\end{array}$ & $\begin{array}{l}21.3 \\
20.7 \\
19.9\end{array}$ & $\begin{array}{l}14 \\
12 \\
12\end{array}$ & $\begin{array}{l}20 \\
20 \\
20\end{array}$ & $\begin{array}{l}35.4 \\
35.0 \\
35.2\end{array}$ \\
\hline T. & 11.4 & L2 & 19.0 & 5 & 11 & 33.2 \\
\hline B. & 18.4 & $\begin{array}{l}\text { L3 } \\
\text { L1 } \\
\text { R3 } \\
\text { R1 }\end{array}$ & $\begin{array}{l}22.4 \\
23.8 \\
22.8 \\
28.5\end{array}$ & $\begin{array}{l}9 \\
9 \\
8 \\
3\end{array}$ & $\begin{array}{r}15 \\
13 \\
14 \\
7\end{array}$ & $\begin{array}{l}33.5 \\
33.8 \\
35.1 \\
35.8\end{array}$ \\
\hline Li. & 19.1 & $\begin{array}{l}\text { L1 } \\
\text { L3 } \\
\text { R1 } \\
\text { R3 }\end{array}$ & $\begin{array}{l}20.4 \\
19.9 \\
20.3 \\
19.5\end{array}$ & $\begin{array}{r}8 \\
15 \\
6 \\
13\end{array}$ & $\begin{array}{l}17 \\
29 \\
12 \\
-\end{array}$ & $\begin{array}{l}32.1 \\
33.1 \\
33.6 \\
31.6\end{array}$ \\
\hline M. & 19.0 & $\begin{array}{l}\text { L1 } \\
\text { R1 } \\
\text { R3 }\end{array}$ & $\begin{array}{l}24.0 \\
23.8 \\
23.2\end{array}$ & $\begin{array}{r}12 \\
9 \\
10\end{array}$ & $\begin{array}{l}17 \\
14 \\
17\end{array}$ & $\begin{array}{l}33.8 \\
34.7 \\
34.3\end{array}$ \\
\hline La.* & 21.5 & $\mathrm{R} 2$ & 21.9 & 23 & 39 & 33.8 \\
\hline
\end{tabular}

* Feet previously immersed in cold water $\left(22^{\circ} \mathrm{C}\right.$.) for 22 minutes. 
A conspicuously delayed reaction was observed in subject La. (Table I) after the feet had been cooled by immersing them in water at $22^{\circ} \mathrm{C}$. for 22 minutes. In spite of the delay the temperature finally reached $33.8^{\circ} \mathrm{C}$. It is certain that the delay in this instance was not due to any real abnormality of circulation since the same subject on two occasions reacted within the usual time (Table II) when the feet had cooled spontaneously. On account of this delayed response the use of a cold bath to reduce the temperatures of the extremities was avoided in all subsequent observations.

TABLE II

Effect of clothing on time of rise in skin temperature

\begin{tabular}{|c|c|c|c|c|c|c|c|c|}
\hline & \multicolumn{4}{|c|}{ Subject G. } & \multicolumn{4}{|c|}{ Subject La. } \\
\hline & $\begin{array}{l}\text { Room } \\
\text { tem- } \\
\text { per- } \\
\text { ature }\end{array}$ & $\begin{array}{l}\text { Temper- } \\
\text { ature of } \\
\text { toes } \\
\text { before } \\
\text { rise }\end{array}$ & $\begin{array}{c}\text { Time } \\
\text { from } \\
\text { immer- } \\
\text { sion } \\
\text { to start } \\
\text { of rise }\end{array}$ & $\begin{array}{l}\text { Time to } \\
\text { reach } \\
32^{\circ} \mathrm{C} \text {. }\end{array}$ & $\begin{array}{c}\text { Room } \\
\text { tem- } \\
\text { per- } \\
\text { ature }\end{array}$ & $\begin{array}{c}\text { Temper- } \\
\text { ature of } \\
\text { toes } \\
\text { before } \\
\text { rise }\end{array}$ & $\begin{array}{l}\text { Time } \\
\text { from } \\
\text { immer- } \\
\text { sion } \\
\text { to start } \\
\text { of rise }\end{array}$ & $\begin{array}{l}\text { Time to } \\
\text { reach } \\
32^{\circ} \mathrm{C} .\end{array}$ \\
\hline Without blankets & $\begin{array}{l}\bullet C . \\
20.0\end{array}$ & $\begin{array}{c}\bullet C . \\
19.9 \\
20.7 \\
21.3\end{array}$ & $\begin{array}{c}\text { minutes } \\
12 \\
12 \\
14\end{array}$ & $\begin{array}{c}\text { minutes } \\
20 \\
20 \\
20\end{array}$ & $\begin{array}{l}{ }^{\circ} C . \\
16.0\end{array}$ & $\begin{array}{l}\bullet C . \\
17.2 \\
17.9 \\
20.1\end{array}$ & $\begin{array}{c}\text { minutes } \\
7 \\
7 \\
6\end{array}$ & $\begin{array}{c}\text { minutes } \\
22 \\
13 \\
9\end{array}$ \\
\hline With blankets & 19.5 & $\begin{array}{l}18.9 \\
19.2 \\
20.1\end{array}$ & $\begin{array}{r}9 \\
10 \\
9\end{array}$ & $\begin{array}{l}14 \\
15 \\
14\end{array}$ & 16.0 & $\begin{array}{l}18.1 \\
18.3 \\
20.4\end{array}$ & $\begin{array}{r}14 \\
12 \\
7\end{array}$ & $\begin{array}{l}29 \\
23 \\
15\end{array}$ \\
\hline
\end{tabular}

The time elapsing between immersion of the forearms in warm water and the appearance of vasodilatation in the feet is probably affected by a number of factors, some of which are not easy to evaluate. A few of the more likely factors have been investigated. Lewis and Pickering (7) have already shown that the time interval between warming the body and the rise of temperature of the fingers "is influenced by the initial temperature of the extremities, being delayed by coldness." Similar results have been observed in the temperature changes produced by vasodilatation in the feet (Table I, subject B.). As the initial temperatures of the extremities will vary widely in different observations, it is doubtful whether any significance can be attached to the variations in the time elapsing between immersion and the beginning of the temperature rise in the other extremities.

The observations upon normal subjects have been carried out at both high and low room temperatures. The temperature of the room air alone appears to have little influence upon the time at which vasodilatation begins (Table I). Thus on one occasion with the room temperature between 11 and $12^{\circ} \mathrm{C}$. the temperature of the toe (initially $19.0^{\circ} \mathrm{C}$.) began to rise 5 minutes after immersion of the arms, and was above $32^{\circ} \mathrm{C}$. in 11 
minutes. The subject on this occasion was warmly clad. Another subject, at a room temperature of $20.0^{\circ} \mathrm{C}$., did not show the response until 12 to 14 minutes after the forearms were immersed.

As this type of vasodilatation apparently results from warming the body, it was thought that the clothing of the subject might influence the time relations of the response, and that in a lightly clad subject exposed to a very low room temperature the response might be delayed or even absent. Two observations were carried out with subjects clad only in short trunks and sleeveless cotton jersey at room temperatures of 19.5 to $20^{\circ} \mathrm{C}$. and $16^{\circ} \mathrm{C}$. respectively. In both instances after the forearms were immersed in warm water the temperatures of the toes began to rise at the usual time and reached $32^{\circ} \mathrm{C}$. within 22 minutes (Table II). The observations were then repeated under similar conditions with the exception that while the arms were immersed in hot water the subject was enveloped from neck to ankles in two heavy blankets. In one subject (G.) the temperature of the toes rose more promptly while in the other subject (La.) the response appeared later (Table II). Thus the manner in which the subject is clad does not appear to exert any conspicuous effect upon the response at room temperatures of 20 and $16^{\circ} \mathrm{C}$.

\section{The mechanism by which warming one forearm produces vasodilatation in the opposite hand}

There are two possible mechanisms by which this type of vasodilatation may be initiated. The response may be due to sensory impulses from the limbs immersed in hot water, or it may be due to the heat carried into the body by the venous blood, returning from the warmed limbs. Pickering (9) has already shown that the central mechanism controlling vasomotor tone in the extremities is affected by changes in body temperature amounting to less than $0.1^{\circ} \mathrm{C}$.

In 1911, G. N. Stewart (10) reported certain calorimetric studies on the rate of blood flow in the hands. He found in two experiments on normal subjects that immersing one hand in warm water increased the blood flow through the opposite hand. In one instance a measurable increase in blood flow was observed two minutes, and in the other five minutes, after the opposite hand was immersed in warm water $\left(43^{\circ} \mathrm{C}\right.$.). In the first observation the temperature of the water in the calorimeter was $30^{\circ} \mathrm{C}$. and in the second $24^{\circ} \mathrm{C}$. Stewart (10) regarded the phenomenon as "reflex vasomotor excitation," and attributed a part of the delay in the response to the fact that any change in the temperature of the water in the calorimeter must necessarily "lag somewhat behind the corresponding change in blood flow."

In our observations the time elapsing between immersion of the limbs in hot water and the rise of temperature in the other limbs amounted to between 5 and 15 minutes. This delay in the appearance of the response 
suggests that this type of vasodilatation is not due to a simple nervous reflex. The general feeling of warmth which precedes the rise in digital skin temperature, and the generalized perspiration, suggest, moreover, that the vasodilatation results from an increase in body warmth.

More conclusive evidence that in our observations vasodilatation was not produced by afferent nerve impulses but was dependent upon the flow of blood through the limbs immersed in hot water was obtained in the following manner. One hand was exposed to an air temperature of $\mathbf{1 8 . 5}$ to $20.0^{\circ} \mathrm{C}$. A pneumatic cuff was wrapped about the opposite upper arm and inflated suddenly from a reservoir to a pressure well above the systolic level. The forearm, with the circulation cut off, was immersed in warm water $\left(42.5\right.$ to $44.6^{\circ} \mathrm{C}$.) and the temperatures of the fingers of the opposite hand were recorded every minute. After 15 minutes the blood vessels of the warmed forearm were released for a period of two minutes, when blood flow was again stopped. After a second period of occlusion for 10 minutes the circulation was released again for one minute and then occluded once more for a final period of 10 minutes. The arm was kept in the bath until the customary response in the fingers of the opposite hand had occurred (Figure 5). This procedure was carried out in two

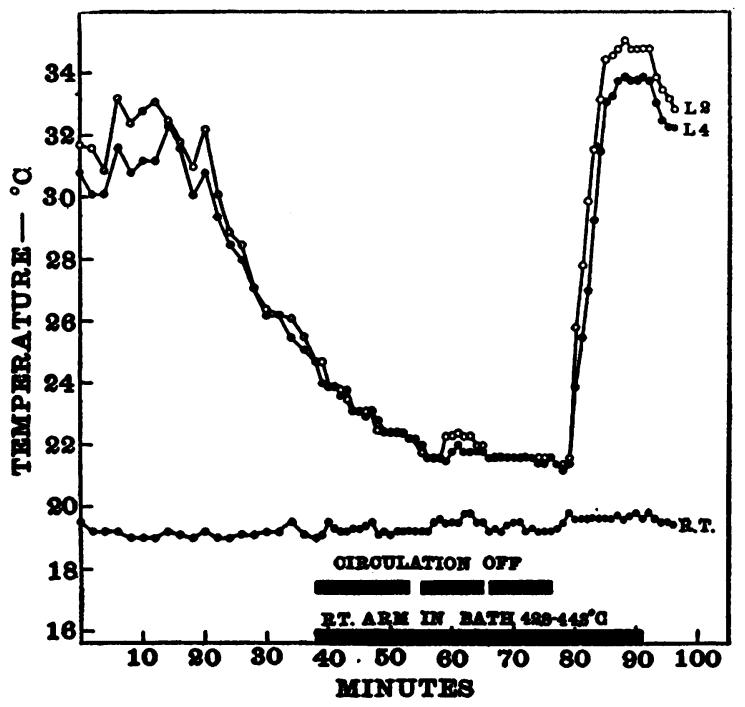

Fig. 5. Showing the Delayed Vasodilator Response Produced by Occluding Circulation in the Immersed Forearm (Right)

$L 2$, left second finger; $L 4$, left fourth finger; R.T., room temperature.

observations, while in the third the occlusion was divided into two periods of 20 minutes and 15 minutes, with an interval of 3 minutes during which the circulation was released. Thus in all three observations the circulation to the arm in the bath was completely occluded for a total period of 
35 minutes. In all three experiments the temperature of the fingers of the opposite hand failed to rise until some minutes after the circulation had been finally reestablished in the immersed forearm.

The results of these three observations are summarized in Table III (a), for comparison with the results of six control observations in Table III (b). When the blood vessels of the arm in the bath were occluded for

TABLE III

Effect of occluding the circulation of the immersed arm

\begin{tabular}{|c|c|c|c|c|c|c|c|c|c|c|c|}
\hline \multicolumn{6}{|c|}{$\begin{array}{l}\text { With occlusion of the circulation of the immersed } \\
\text { arm for } 35 \text { minutes }\end{array}$} & \multicolumn{6}{|c|}{$\begin{array}{c}(b) \\
\text { Without occlusion }\end{array}$} \\
\hline $\begin{array}{l}\text { Sub- } \\
\text { ject }\end{array}$ & $\begin{array}{l}\text { Room } \\
\text { tem- } \\
\text { pera- } \\
\text { ture }\end{array}$ & $\begin{array}{l}\text { Tem- } \\
\text { pera- } \\
\text { ture of } \\
\text { fingers } \\
\text { before } \\
\text { rise }\end{array}$ & $\begin{array}{l}\text { Time } \\
\text { from } \\
\text { immer- } \\
\text { sion to } \\
\text { start } \\
\text { of rise }\end{array}$ & $\begin{array}{l}\text { Time } \\
\text { to } \\
\text { reach } \\
32^{\circ} \mathrm{C} .\end{array}$ & $\begin{array}{l}\text { Bath } \\
\text { tem- } \\
\text { pera- } \\
\text { ture }\end{array}$ & $\begin{array}{c}\text { Sub- } \\
\text { ject }\end{array}$ & $\begin{array}{l}\text { Room } \\
\text { tem- } \\
\text { pera- } \\
\text { ture }\end{array}$ & $\begin{array}{l}\text { Tem- } \\
\text { pera- } \\
\text { ture of } \\
\text { fingers } \\
\text { before } \\
\text { rise }\end{array}$ & $\begin{array}{l}\text { Time } \\
\text { fromer } \\
\text { immmer- } \\
\text { sion to } \\
\text { start } \\
\text { of rise }\end{array}$ & $\begin{array}{l}\text { Time } \\
\text { to } \\
\text { reach } \\
32^{\circ} \mathrm{C} .\end{array}$ & $\begin{array}{l}\text { Bath } \\
\text { tem- } \\
\text { pera- } \\
\text { ture }\end{array}$ \\
\hline La. & $\begin{array}{c}{ }^{\circ} C . \\
18.5\end{array}$ & $\begin{array}{c}{ }^{\circ} C . \\
19.9 \\
19.6\end{array}$ & 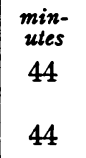 & $\begin{array}{c}\begin{array}{c}\min - \\
\text { utes }\end{array} \\
48 \\
\\
48\end{array}$ & $\begin{array}{c}\bullet C . \\
42.5 \\
\text { to } \\
43.8\end{array}$ & G. & $\begin{array}{l}{ }^{\circ} C . \\
17.0\end{array}$ & $\begin{array}{c}{ }^{\circ} C . \\
20.2 \\
19.8\end{array}$ & 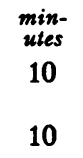 & $\begin{array}{c}\text { min- } \\
\text { utes } \\
16 \\
16\end{array}$ & $\begin{array}{c}\circ C . \\
42.8 \\
\text { to } \\
43.5\end{array}$ \\
\hline La. & 19.5 & $\begin{array}{l}20.8 \\
20.7\end{array}$ & $\begin{array}{l}45 \\
44\end{array}$ & $\begin{array}{l}51 \\
50\end{array}$ & $\begin{array}{c}43.0 \\
\text { to } \\
44.6\end{array}$ & G. & 19.5 & $\begin{array}{l}21.1 \\
21.3\end{array}$ & $\begin{array}{l}9 \\
8\end{array}$ & $\begin{array}{l}14 \\
11\end{array}$ & $\begin{array}{c}42.9 \\
\text { to } \\
43.6\end{array}$ \\
\hline \multirow[t]{4}{*}{ G. } & 19.5 & $\begin{array}{l}21.2 \\
21.4\end{array}$ & $\begin{array}{l}42 \\
42\end{array}$ & $\begin{array}{l}47 \\
46\end{array}$ & $\begin{array}{c}42.8 \\
\text { to } \\
44.3\end{array}$ & La. & 16.5 & $\begin{array}{l}20.3 \\
20.7\end{array}$ & $\begin{array}{l}5 \\
5\end{array}$ & $\begin{array}{l}13 \\
10\end{array}$ & $\begin{array}{c}42.7 \\
\text { to } \\
43.4\end{array}$ \\
\hline & & & & & & La. & 20.5 & $\begin{array}{l}21.2 \\
21.5\end{array}$ & $\begin{array}{l}6 \\
5\end{array}$ & $\begin{array}{r}9 \\
11\end{array}$ & $\begin{array}{c}43.7 \\
\text { to } \\
45.0\end{array}$ \\
\hline & & & & & & La. & 15.5 & 22.9 & 6 & 10 & $\begin{array}{c}44.0 \\
\text { to } \\
45.0\end{array}$ \\
\hline & & & & & & J. & 14.5 & 23.8 & 10 & 16 & $\begin{array}{c}43.8 \\
\text { to } \\
45.3\end{array}$ \\
\hline
\end{tabular}

35 minutes the temperature response in the opposite hand never began before the forty-second minute. In the six control observations, in which one forearm was immersed without occlusion, the longest period before the temperature response began was only 10 minutes. Cutting off the circulation in the immersed forearm, therefore, conspicuously delayed the appearance of vasodilatation in the opposite hand. This effect cannot be attributed to interference with the function of the sensory nerves of the immersed limb. It is obvious that the only afferent nerves which could possibly be involved are those concerned with the perception of warmth. 
When the circulation is occluded a bath temperature of 43.0 to $43.5^{\circ} \mathrm{C}$. produces an almost intolerable sensation of heat. In addition, heat sensation was tested at frequent intervals by pouring a small amount of water at a temperature of 47 to $48^{\circ} \mathrm{C}$. into the bath near the fingers and forearm. This water, even though mixed with the water in the bath, invariably felt disagreeably hot to the subject. According to this test, heat sensation was present and very slightly or not at all diminished throughout the entire period of occlusion. This agrees with the work of Lewis, Pickering, and Rothschild (11), who reported that heat sensation is still acute after the circulation of the forearms (at $30^{\circ} \mathrm{C}$.) has been occluded for 35 minutes without interruption.

The delayed response accompanying occlusion of the circulation, therefore, presents strong evidence against the hypothesis that this type of vasodilatation results from afferent nerve impulses originating in the immersed limb. It seems clear that the vasodilator response depends on the return of warmed blood from the immersed extremity. ${ }^{1}$ Rectal temperature was measured thermo-electrically on three occasions in order to learn whether vasodilatation in the extremities was associated with large changes in body temperature. In observation 4 (Figure 2) the rectal temperature fell very slightly during the preliminary control period, when the subject felt definitely chilly, and rose again slightly, shortly after the legs had been immersed in hot water. The rise in rectal temperature followed the appearance of subjective sensations of warmth. On another occasion the changes observed were similar in direction but of slightly greater magnitude $\left(0.6^{\circ} \mathrm{C}\right.$.). In a third observation the greatest variation observed was $0.1^{\circ} \mathrm{C}$. Since this type of vasodilatation is dependent upon the return of warmed blood from the immersed extremity, it follows that the central nervous mechanism, which responds to warming of the body by diminishing vasoconstrictor tone in the extremities, is sensitive to very small changes in body temperature; otherwise, the rise in rectal temperature would have been greater.

The effector mechanism of the vasodilator response to warming the body has already been studied by Lewis and Pickering (7), who showed that the response is absent in the sympathectomized extremity. They concluded that the effector mechanism lies purely in the sympathetic nerves to the limb and is not antidromic.

1 More recently this point was tested further in a patient with paraplegia due to transverse myelitis. Pain and temperature sensations were lost anteriorly below the level of the seventh dorsal segment and posteriorly below the level of the tenth dorsal segment. The anesthetic legs were immersed in warm water at a temperature of $43^{\circ} \mathrm{C}$. Twelve minutes later the subject felt warm and began to perspire. The temperatures of the fingers, originally 23.3 to $23.6^{\circ} \mathrm{C}$., began to rise fifteen minutes after the legs were immersed, exceeding $32^{\circ} \mathrm{C}$. by the twenty-fifth minute after immersion. In this instance, the vasodilatation in the fingers occurred without sensation of warmth in the immersed extremities. This provides additional evidence that the type of vasodilatation here described is due to the return of warmed blood from the immersed limbs. 


\section{CLINICAL STUDIES}

In ten observations on the spontaneously cool lower extremities of six normal subjects the digital skin temperature began to rise within 15 minutes after the forearms were immersed in warm water. The skin temperature in all but one of these observations exceeded $32.0^{\circ} \mathrm{C}$. by the 29 th minute. The amount of vasodilatation produced by this relatively simple procedure is apparently as great as the vasodilatation produced by spinal anesthesia or nerve block. The method was used; therefore, in studying a series of patients with clinical evidence of inadequate circulation in the lower extremities.

Room temperature was usually kept between $18^{\circ} \mathrm{C}$. and $20^{\circ} \mathrm{C}$. The lower extremities were permitted to cool spontaneously and then the forearms were immersed in warm water for 35 minutes, a period definitely longer than that required for a complete response in normal subjects. Abnormal findings were checked by other methods of examination. The following cases exemplify the clinical usefulness of this simple procedure, when it is necessary to distinguish between organic occlusion and spasm of the peripheral blood vessels in the lower extremities.

Case 1. B. S., an Austrian Hebrew male, aged 58, complained of pain and swelling in the right lower leg, accompanied by symptoms of intermittent claudication in the right calf. The symptoms had begun 8 months prior to examination and had grown progressively worse. At night the right foot habitually became cold and painful even though protected by blankets or a warmed cradle. No history of migratory phlebitis could be elicited. The patient smoked about 10 cigarettes per day.

On examination the systolic blood pressure was 155 and the diastolic 90; the brachial and radial arteries were moderately sclerotic. The left foot was normal in appearance while the right foot showed marked rubor and, when dependent, definite cyanosis of the sole and of the distal phalanges of the toes. The distal portion of the foot blanched conspicuously when elevated and the return of color was delayed. No pulsation could be felt in the dorsalis pedis or the posterior tibial arteries of either foot. X-ray examination revealed a moderate and equal grade of calcification of the arteries of both feet and both lower legs. There was marked osteoporosis of all the bones of the right foot.

The patient's feet were exposed to room air at a temperature of 18 to $19^{\circ} \mathrm{C}$. He was clothed in a shirt, heavy underwear and trousers. The lower extremities were exposed as far as the knees. The temperatures of the right and left great toes were fairly constant during the control period of 30 minutes (Figure 6, lower chart).

Immersing the arms in water at 44.5 to $45.0^{\circ} \mathrm{C}$. for 35 minutes caused the temperature of the left great toe to rise slowly to a maximum of $27.7^{\circ} \mathrm{C}$. but the temperature of the right great toe did not change. These abnormal responses suggested the presence of slight organic obstruction to circulation in the left foot, and marked organic obstruction in the right foot.

The changes in skin temperature during spinal anesthesia confirmed these findings (Figure 6, upper chart). The patient, clad in hospital shirt and covered by a sheet, lay on a bed with the legs and feet exposed. Thermal 
junctions were fixed to the right and left great toes, close to the bases of the nails, and skin temperatures were recorded for a preliminary period of 20 minutes. The room temperature varied between 18 and $19^{\circ} \mathrm{C}$. Fifty mgm. of neocaine dissolved in spinal fluid were injected into the spinal canal between

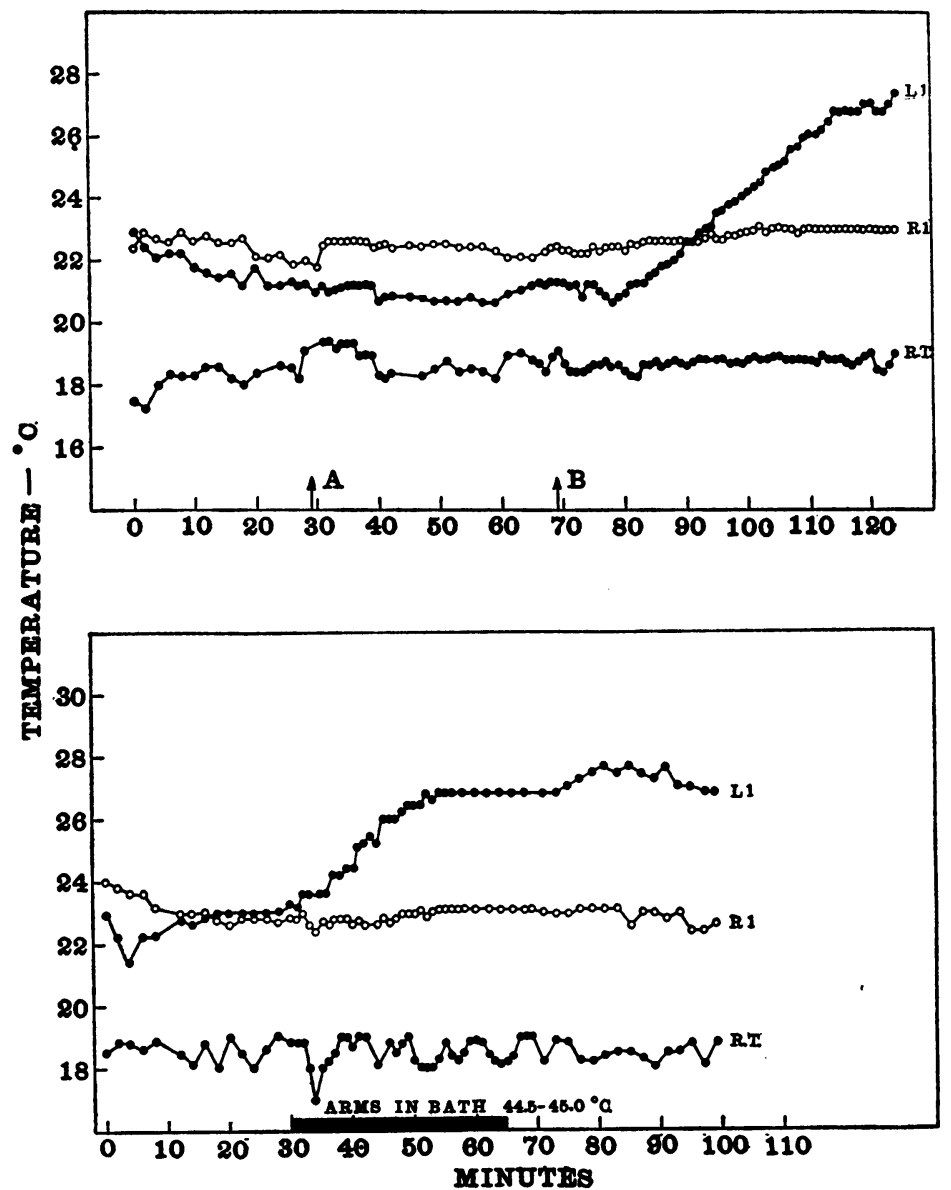

Fig. 6. Upper: Showing Changes in Skin Temperature of the Left First ( $L 1)$ and Right First $(R 1)$ Toes After Spinal Anesthesia in a Patient with Arteriosclerosis.

$A$. Fifty mgm. neocaine injected into the spinal canal between 4 th and 5 th lumbar vertebrae. $B$. Fifty $\mathrm{mgm}$. neocaine injected into the spinal canal between $3 \mathrm{~d}$ and 4 th lumbar vertebrae. R.T., room temperature.

\section{Lower: Showing Changes in Skin Temperature of Same Toes During IMMERSION OF FOREARMS IN WARM WATER}

the third and fourth lumbar vertebrae. The perineum became anesthetic, but sensation in the legs remained normal. At the 69th minute another $50 \mathrm{mgm}$. of neocaine was injected into the spinal canal between the second and third lumbar vertebrae and thoroughly mixed with spinal fluid. By the 85th 
minute the feet, legs and thighs were completely anesthetic. Subsequently, the temperature of the left first toe rose slowly and steadily to $27.4^{\circ} \mathrm{C}$. while the temperature of the right first toe did not change. The graphs in Figure 6 show that immersing the arms in warm water and spinal anesthesia affected the skin temperature similarly. In the left great toe the maximum temperature and the rate of the rise were similar in both procedures. The temperature of the right great toe did not change significantly in either case.

The surface temperature changes in this case indicate a high grade of organic obliteration in the blood vessels of the right foot, with mixed spasm and a mild grade of organic obliteration in the blood vessels of the left foot. The obliterative changes were probably due to arteriosclerosis but the patient was one of those in whom thrombo-angiitis obliterans could not be definitely excluded by clinical examination.

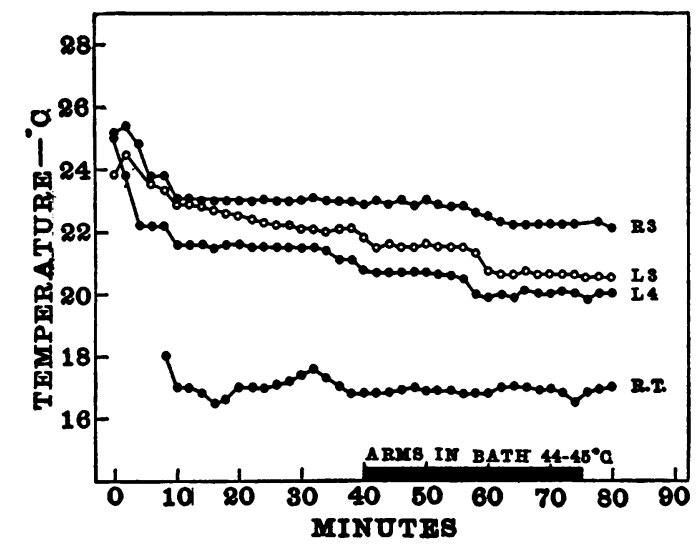

Fig. 7. Showing Skin Temperature of the Right Third ( $R 3$ ) AND Left Third and Fourth $(L 3, L 4)$ Toes, While the Forearms were IMMERSED IN WARM WATER.

$R . T$., room temperature. The patient had advanced thrombo-angiitis obliterans involving both feet.

Case 2. N.,2 a white male, aged 26, was admitted to the University Hospital on December 2, 1931, with a chief complaint of pain in the lower extremities. For two years the patient had suffered to an increasing degree from generalized pain in the lower legs; intermittent claudication had been present for eight months prior to admission. Discolored areas were first observed on the great toes about nine weeks before admission. The patient smoked approximately 20 cigarettes per day.

On examination his blood pressure was normal; there was no evidence of arteriosclerosis nor of diabetes. The skin of both feet showed purplish red discoloration with a spot of dry gangrene about $4 \mathrm{~cm}$. in diameter on the mesial surface of each great toe. X-ray examination revealed no calcification of the vessels of the legs. The bones of the left foot and the lower end of the left tibia were considerably rarefied. The vasomotor index, determined by

2 We wish to express our indebtedness to Dr. George P. Müller for his kindness in permitting us to include this case and to Dr. Lee Rademaker for the results of the vasomotor index test. 
Dr. Lee Rademaker, was zero for both feet. The patient improved somewhat under conservative treatment and was discharged December 9, 1931, with a diagnosis of thrombo-angiitis obliterans affecting both lower extremities.

He was readmitted to the Hospital on March 19, 1932, with more extensive gangrene of both great toes. At this time it was necessary to remove the terminal phalanx of the left great toe and the entire right great toe.

The vasodilator response in the lower extremities was tested several days after operation. The patient was seated in bed with the feet exposed to an air temperature of $17.0^{\circ} \mathrm{C}$. Small gauze dressings covered the sites of amputation. The four lateral toes of each foot were cyanosed and both feet were cold as far as the ankles. Thermal junctions were fixed to the dorsal surfaces of the distal phalanges of the right third and the left third and fourth toes. As shown in Figure 7 the skin temperature, originally about 24 to $25^{\circ} \mathrm{C}$. gradually fell, during the course of 40 minutes, to between 20 and $23^{\circ} \mathrm{C}$.

The forearms were then immersed in water baths $\left(44\right.$ to $45^{\circ} \mathrm{C}$.) for 35 minutes. Perspiration appeared on the patient's forehead four minutes after the forearms were immersed. As indicated in Figure 7 the surface temperature of the toes showed no rise but, on the contrary, a slow decline. The test was repeated later with a room temperature of $21^{\circ} \mathrm{C}$. and a similar result was obtained. In the latter observation the digital temperatures ranged from 25.0 to $26.2^{\circ} \mathrm{C}$. before immersion of the forearms and from 24.0 to $25.4^{\circ} \mathrm{C}$. at the end of the period of immersion.

The history and physical findings are typical of thrombo-angiitis obliterans. Immersing the forearms in warm water produced no change in the skin temperature of the toes. This indicates the presence of a very severe grade of organic occlusion of the vessels of both feet,-a finding which is in agreement with the results of the vasomotor index test.

Case 3. R., a white female, aged 24, complained of pain in all four extremities. It had occurred during the previous 7 or 8 years, generally when the patient was fatigued, and was more severe in the lower extremities. There was no history of intermittent claudication, and the pain had no direct relation to exercise. It was described as a dull ache, and occurred as readily in a warm room as in a cold one. The patient had never noticed blue fingers or toes, but numbness was often experienced. The pain was not typical of any of the usually described vascular disorders. She had never had frost bite or chilblains.

On examination in a warm room $\left(22^{\circ} \mathrm{C}\right.$.) the toes were definitely cold, but only slightly, if at all, cyanotic. Neither the dorsalis pedis nor the posterior tibial arteries could be palpated in either foot. This was probably due to brawny edema of the ankles and dorsa of both feet. The edema did not pit on pressure but according to the patient, it increased during the day and disappeared during the night. Both radial and ulnar pulses were normal; the systolic blood pressure was 118 and the diastolic, 88. The patient was examined in order to decide whether there was any structural abnormality impeding blood flow in the lower extremities.

Immersing the feet for 20 minutes in a bath at $15^{\circ} \mathrm{C}$. failed to produce the spasm typical of Raynaud's disease. The feet were then dried and exposed to the room air at a temperature of 21 to $22^{\circ} \mathrm{C}$. Thirty minutes later both forearms were immersed in water at a temperature of $44^{\circ} \mathrm{C}$. Eleven minutes after the forearms were immersed the surface temperatures of the first toes of both feet began to rise and 22 minutes after immersion were well above $32^{\circ} \mathrm{C}$.

The vasodilator response in the lower extremities of this patient was entirely normal, despite the fact that it was impossible to feel pulsation in 
the arteries of either foot. This case report illustrates the value of the procedure in differentiating diminished blood flow arising from spasm and from structural disease of the blood vessels.

\section{DISCUSSION}

The method which has just been described has certain advantages over the more complicated procedures by which vasodilatation may be produced. The test can be carried out with equal facility in patients whether ambulatory or in bed. It has been found particularly useful in those cases in which the use of spinal or general anesthesia was contraindicated.

There are two conditions, however, in which vascular spasm depends to a certain extent on the direct local effects exerted on the peripheral blood vessels by cold. Lewis (5) has shown that the arterial spasm of Raynaud's disease may be induced by cold even when vasoconstrictor impulses are removed by nerve block or by sympathetic ganglionectomy. In patients showing typical acrocyanosis arteriolar spasm is apparently induced similarly by cold (Lewis and Landis (12)). It is conceivable that in these two conditions the mere removal of vasoconstrictor impulses to the cooled extremity might not relax a vascular spasm stimulated by local cold. Scott and Morton (6) have stated that in certain cases of Raynaud's disease blocking the posterior tibial nerve produced only delayed or partial elevation of skin temperature. In two cases of acrocyanosis of the feet we found that immersing the forearms in warm water may fail to relax the arteriolar spasm in the lower extremities though the response, when it occurs, is normal in type. A full description of these patients will be published later. Lewis and Pickering (7) found also in one case of acrocyanosis of the hands that warming the body produced a response which, once initiated, was of the normal type.

The vasodilator response in the lower extremities produced by immersing the forearms in warm water $\left(43\right.$ to $45^{\circ} \mathrm{C}$.) for 35 minutes has, except in acrocyanosis, been practically identical with vasodilatation produced by other procedures such as spinal anesthesia, nerve block, or the injection of typhoid vaccine. If the digital temperature rises above $32^{\circ} \mathrm{C}$. organic occlusion of the blood vessels is definitely excluded. If the digital temperature fails to rise, or rising fails to reach $32^{\circ} \mathrm{C}$., the presence of organic obstruction is indicated; but this conclusion should probably be verified by some other method of examination. The simplicity of the test favors its use as a preliminary procedure in the study of cases showing clinical evidence of peripheral vascular disease.

\section{SUMMARY}

1. In normal subjects immersing the forearms in warm water (43 to $45^{\circ} \mathrm{C}$.) produces vasodilatation in the lower extremities. In ten observations on the spontaneously cool extremities of six normal subjects the 
rise in digital skin temperature began within 15 minutes after immersing the forearms in water. The skin temperature in all but one of these observations exceeded $32^{\circ} \mathrm{C}$. by the twenty-ninth minute.

2. The immersion of one forearm or one leg in warm water produces vasodilatation in the other extremities.

3. This type of vasodilatation apparently depends upon the return of warmed blood from the immersed extremity.

4. The rise in rectal temperature produced by immersing two limbs in warm water ranged in three experiments from $0.1^{\circ} \mathrm{C}$. to $0.6^{\circ} \mathrm{C}$.

5. Three cases illustrating vasodilator responses in certain types of vascular disorders of the extremities are reported. With this method of producing vasodilatation, if the digital temperature rises above $32^{\circ} \mathrm{C}$. organic occlusion of the vessels supplying the extremity may be excluded.

\section{BIBLIOGRAPHY}

1. Brown, G. E., J. Am. Med. Assoc., 1926, lxxxvii, 379. The Treatment of Peripheral Vascular Disturbances of the Extremities.

2. Morton, J. J., and Scott, W. J. M., J. Clin. Invest., 1930, ix, 235. The Measurement of Sympathetic Vasoconstrictor Activity in the Lower Extremities.

3. Morton, J. J., and Scott, W. J. M., New England J. Med., 1931, cciv, 955. Methods for Estimating the Degree of Sympathetic Vasoconstriction in Peripheral Vascular Diseases.

4. White, J. C., J. Am. Med. Assoc., 1930, xciv, 1382. Diagnostic Blocking of Sympathetic Nerves to Extremities with Procaine.

5. Lewis, T., Heart, 1929, xv, 7. Experiments Relating to the Peripheral Mechanism Involved in Spasmodic Arrest of the Circulation in the Fingers: A Variety of Raynaud's Disease.

6. Scott, W. J. M., and Morton, J. J., J. Am. Med. Assoc., 1931, xcvii, 1212. The Differentiation of Peripheral Arterial Spasm and Occlusion in Ambulatory Patients.

7. Lewis, T., and Pickering, G. W., Heart, 1931, xvi, 33. Vasodilatation in the Limbs in Response to Warming the Body; with Evidence for Sympathetic Vasodilator Nerves in Man.

8. Grant, R. T., and Bland, E. F., Heart, 1931, xv, 385. Observations on Arteriovenous Anastomoses in Human Skin and in the Bird's Foot with Special Reference to the Reaction to Cold.

9. Pickering, G. W., 1932. To be published.

10. Stewart, G. N., Heart, 1911, iii, 33 and 76. Studies of the Circulation in Man. I. The Measurement of the Blood Flow in the Hands. II. The Effect of Reflex Vasomotor Excitation on the Blood Flow in the Hand.

11. Lewis, T., Pickering, G. W., and Rothschild, P., Heart, 1931, xvi, 1. Centripetal Paralysis Arising Out of Arrested Blood Flow to the Limb, Including Notes on a Form of Tingling.

12. Lewis, T., and Landis, E. M., Heart, 1930, xv, 229. Observations Upon the Vascular Mechanism in Acrocyanosis. 